\title{
世代間学歴移動の社会的効果
}

再分配政策への賛否に着目して

\section{1. 問題関心}

これまでの教育社会学の研究では, 父親の学歴と本人の学歴の異同のメカニズム に関する研究が行われてきた。しかし，そうしたなかで父と本人との学歴の異同が

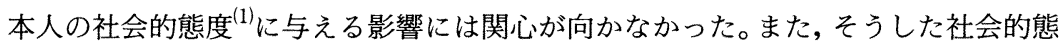
度が集積して社会に与える影響を予測するという点にも関心が向かなかった。実際 のところ，世代間で学歴が変化する（あるいは変化しない）ということはどのよう な社会的効果を持つのだろうか。その社会的効果を検討するのが本論文の課題とな る。そして, その効果を見るために社会的態度の指標として着目するのが, 所得再 分配政策（以下，「再分配政策」と略記）への賛否である。

再分配政策への賛否に着目する理由は，再分配政策が次世代の教育機会の開放性 に影響を与えるからである。再分配政策を実施せずに経済的格差がひどく開いてし まった場合，教育機会の開放性は自ずと低くなるであろう。逆に，再分配政策を行 っておくことは，次世代の教育機会の開放性の土台を作ることになるのである。

この点, 社会経齐的な格差拡大に関する主張は後を断たないなかで（佐藤 2000 , 苅谷 2001), 日本においても2000年代に入ってから新自由主義的な改革が本格化し ている。格差拡大と財政縮小の間で, 再分配のあり方というものが社会的な課題と なっているのである。ここでもし仮に，不利な地位から上昇してきた人が再分配に 賛成しやすいということになれば，格差を縮めることはさらに継続的に格差を縮め ていく可能性を秘めている。逆に, 有利な地位を継承した人ほど再分配に賛成しに

東京大学大学院 
くいという結果が出れば，すでにある格差がさらなる格差を継続的に拡大していく 可能性がある。そこで問題になるのが，どのような人々が再分配政策に賛成してい るか, ということである。親の学歴と本人の学歷との異同という観点から言えば, 再分配に賛成しやすいのが, 親は義務教育学歴で本人は高等教育学歴に上昇してき た人なのか, それとも, 親から高学歴を継承した人なのか。これを把握することは, 今後の日本社会での機会の開放性と経済的格差の動向を占ううえで重要な課題と言 えよう。

以上のような観点から，問うべき問いは，世代間で学歴が変化すること（あるい は変化しないこと）はどのような社会的効果を持つだろうか，というものである。 その問いに答えるために, 誰が再分配政策に賛成しているのか, という再分配政策 への賛否に着目することにする。

本論文で示されるのは以下のことである。同じ高等教育学歴の人で比べた場合, 父親もまた高等教育学歴で本人も高学歷を継承した人は, 父親が義務教育学歴だっ た家庭の出身で本人が高等教育学歷を持つに至った人ょりも再分配政策に賛成しに くい, ということである。つまり，世代間での高学歷が継承されることは継続的に 格差を拡大させていく社会的効果を持っているということである。

以下では, まず, 題名にある「世代間学歴移動」という用語を定義し, 次に, 先 行研究の検討を行う。その後で, 仮説の設定と分析を行って世代間学歷移動が再分 配政策への賛否に与える影響を検討し, 最後に, それを踏まえて考察を行う。

\section{2.「世代間学歴移動」}

ここでは，まず，「世代間学歴移動」を定義し，次に，それに着目する理由を説明 し, 最後に, 本論文での世代間学歴移動の記号の表し方を説明する。

\section{1.「世代間学歴移動」の定義}

まず，題名にある「世代間学歷移動」という言葉を定義しておこう。世代間学歴 移動とは，世代間社会移動になぞらえて作られた概念であり，父親の学歷と本人の 学歴の変化という意味である。「変化」という言葉を使ったが, 変化がない場合, つ まり父親と本人の学歷が同じ場合も世代間学歴移動のなかに含まれる。

次に, 世代間学歴移動に着目する理由について説明しておかなければならない。 これは二点ある。

第一は, 学歴というものが機会の開放性やメリトクラティックな基準と密接に結 
びついているからである。社会経済的に有利な地位に結びつく高等教育学歴取得の 機会が家庭環境にかかわらず開かれていれば，その社会は機会が開放的な社会だと 言える。後で述べる先行研究でも, 父親と本人の学歴の違いが機会の開放性の捉え 方に影響を与えるものとして前提とされているのである。

第二は, 高等教育の拡大の影響を測るという視点である。これまで日本では高等 教育進学率が量的に拡大してきたし, おそらくこれからも長期的に見れば拡大傾向 にあるだろう。高等教育の機会を開放的にしていくことは人々の意識や態度を介し てどのような効果を社会にもたらすだろうか。あるいは逆に, 高等教育学歴が飽和 していくということはどのような効果をもたらすだろうか。冒頭でも触れたように これまで教育社会学では, 高等教育拡大のメカニズム, つまり父親よりも本人の学 歴が高くなるメカニズムに対して関心が集まっており, それが人々の意識にどのよ うな影響を与えるか, ということについては関心が向かなかった。そうしたなかで 高等教育の機会の開放性を増すことが実際のところ社会にどのような効果を持つの かを把握しておくことは, 今後の高等教育の拡大を考える際に不可欠な作業といえ よう。

最後に, 世代間学歴移動を表す記号法を説明する。本論文では義務教育, 中等教 育, 高等教育をそれぞれ $\mathrm{C}, \mathrm{M}, \mathrm{H}$ と略し, 父学歷, 本人学歴の順で並べて世代間 学歴移動をあらわすこととした。例えば, 本論文で特に着目する $\mathrm{CH}$ とは, 父親が 義務教育学歴で本人が高等教育学歴の人であり, $\mathrm{HH}$ とは, 父親が高等教育学歴で本 人が高等教育学歴の人である。こうすることで, 学歴移動なのか, 学歴継承なのか も, 一目でわかるようになる。本論文では, これらのカテゴリのうち特に $\mathrm{CH}$ と $\mathrm{HH}$ の違いに焦点を当てる。この二つに焦点を当てる理由は二点ある。第一に，すでに 述べたような高等教育を拡大していくことの効果を調べるためには, 本人が高等教 育学歴である人に着目する必要があるということである。第二に, 高等教育学歴の 人々は社会経済的に有利なだけでなく, 政治的にも強い影響力を及ぼすため, これ らの人の再分配政策への賛否のあり方を検討することは，これからの再分配政策の 動向を占う際に必要な作業であると考えられるからである。

それでは先行研究の検討に入ることにしよう。

\section{3. 先行研究}

問題関心でも述べたように，世代間学歴移動を独立変数として投入し，社会的態 度との関係を論じた論文は管見する限りない。そこでここでは, 関連する先行研究 
の問題点を社会移動効果の研究, 世代間学歴移動の研究, 社会意識の研究, 再配分 政策への賛否に関する経済学的研究，の順で検討することにする。

このなかで特に着目するのは, 経済学的研究と社会意識の研究である。経済学的 研究の問題点は, 理論に縛られてしまい, デー夕から涌き上がってくるものを見逃 していることである。それに対し社会意識の研究の問題点は, デー夕から涌き上が ってくるものの解釈に終始し, 社会的背景との関連が薄れてしまったことである。 ここで, 社会的背景との関連が薄れるというのは, 格差社会が問題となるなかでそ こで必要とされる政策との関連が明確な変数を用いていないために, 有効な政策提 言がしにくくなっているという点である。そこで, 本論文では政策との関連が明確 な再分配政策への賛否という変数を用いることにする。

本論文では，デー夕から涌き上がってくるものを拾い上げるという社会意識研究 の長所と, 社会的背景との関連を保っているという経済学的研究の長所とを最大限 に活用することを模索しよう。まず, 社会移動効果の研究を検討し, 次に, 世代間 学歴移動の研究, さらに, 社会意識の研究を見たうえで, 最後に再配分政策への賛 否に関する経済学的研究を検討する。

\section{1. 社会移動効果の研究}

まず，社会移動効果の研究を検討する。これは，世代間社会移動が人々の社会的 態度にどのような影響を与えるかという研究である。これらの研究は，古くはブラ ウの文化変容説にさかのぼ (Blau 1956)。しかし, これに連なる研究は, 統計手 法の開発ばかりに焦点化してしまった傾向がある(和田 1986)。出身階層の影響で もなく, 到達階層の影響でもない社会移動正味の効果をくくりだすことのみに議論 が集中してしまったのである。そこで本論文では, 開発された統計手法を世代間学 歴移動に応用しつつ, 再分配政策への賛否という政策課題と明確な関連を持つ変数 に着目することで，移動効果の研究に新たな課題を見出すこととしたい。

\section{2. 世代間学歴移動に関する研究}

世代間学歷移動に関する研究については，SSM 調査(社会階層と社会移動に関す る全国調査）のデー夕を用いた論文をはじめとして一定の蓄積がある（今田 1979 , 菊池 1990, 片岡 1988)。しかし, そこでの研究関心は学歴が職業達成に与える影 響や高学歴化のメカニズムであり，世代間の学歷移動が社会的態度に与える影響を 探るという視点はない。そうしたなかで，吉川（2005）は「職業階層や経済的な豊 
かさの継承は，学歷の世代間移動の結果として発生しているという側面」に着目し， 職業階層の世代間移動にとって代わるものとして学歴の世代間移動を扱う意義付け をしている。だとするならば，職業階層の世代間移動が社会的態度に与える影響を 検討する研究の代わりに，学歴の世代間移動が社会的態度に与える影響を検討する ほうが得策である。そこで，本論文では，学歷の世代間移動が社会的態度に与える 影響を探ることにするのである。

\section{3. 社会意識の研究}

本論文では，再分配政策への賛否という意識について検討するので，これまでの 社会意識研究の問題点を指摘しておかなければならない。

社会学における人久の社会意識に関する研究は, 階層帰属意識や不公平感の研究 としてたくさんの蓄積がなされてきた(直井 1979, 盛山 1990, 斎藤 1998)。し かし，そうした研究の問題点は，社会的背景との関連を失ってしまっていることで ある。階層㷌属意識の中心論題であった「中流意識論争」の背景にあった問いが「日 本の経済成長とは何であったか」である（盛山 1990）としたら，現在の階層帰属 意識研究の背景にはどのような問いがあるのだろうか。1990年代後半以降の格差拡 大に関する論争を踏まえるならば，懸念すべきは実態としての所得格差や社会移動 の閉鎖性があるにもかかわらず，「中」意識が拡大する中で再分配政策が行われなく なることである。だとするならば，「中」意識を解明することよりも再分配政策への 賛否を検討した方が得策である。なぜなら，階層帰属意識という何を示しているの かがあいまいな変数の決定メカニズムを解明したとしても政策提言は行いにくいの に対し，再分配への賛否という変数は政策課題との関連が明確だからである。残念 ながら，そうした問いのあり方に自覚的になり，格差拡大という社会的背景をふま えたうえで政策の参考になる資料を提供しようとする階層帰属意識研究は管見する 限りないのである。

ただし，階層意識研究や不公平感の枠組みは，再分配の賛否を分析する際にも有 用である。そこで，階層意識研究で用いられてきた準拠集団論 (Merton 1949) をも とに，仮説設定を試みたい。高坂（2000）は，準拠集団をべースにした数理モデル を用いて「中」意識の発生メカニズムを検討している。準拠集団論は，その後パー ソナルネットワークの研究に結びついて検討が行われている(星 2001)。それらの 研究で明らかになったのは，人々は社会全体の階層構造を想定して自分の地位を認 知しているのではなく，身近な人々のなかでの自分の地位によって，社会全体での 
地位を想像しているということである。こうした知見から世代間学歴移動と再分配 への賛否の関係を考えるとき，どのような仮説が考えられるだろうか。

世代間学歷移動と再分配政策への賛否が結びつくメカニズムを，図 1 を見ながら 説明しょう。学歷を継承した人は身近な人の学歷構成に偏りがあり, その狭い学歷 構成をもとに格差は小さいと判断し，その結果，再分配政策には反対しやすくなる。 ここで格差とは, 学歴の違いに伴う社会的地位及び収入の格差のことである。一方, 学歷移動を経験した人は, 身近な人の学歴構成に幅があり, そうした広い学歴構成 をもとに格差が大きいと判断し，その結果，再分配政策には賛成しやすくなるので ある。

図 1 世代間学歴移動と再配分政策への替否との結びつき

$\begin{gathered}\text { 世代間学歴 } \\ \text { 移動の分類 }\end{gathered}$
準拠集団の幅

本論文では，特に本人が高等教育である場合に注目するので，それを考慮すると $\mathrm{CH}$ と $\mathrm{HH}$ について，以下のようなことが推測される。まず，父も自分も高等教育 である人 $(\mathrm{HH})$ は, 身近なところに高等教育学歷の人が多いだろう。その結果, 高 等教育に進学するのは普通のことであり, 機会は誰にも開かれていたと判断する。 したがって再分配政策に賛成しにくくなるのである。それに対し，父が義務教育で 自分が高等教育に上昇してきた人 $(\mathrm{CH})$ は，身近なところに義務教育から高等教育 まで幅広い学歷を持った人がいるであろう。その結果, 機会は誰にも開かれていた わけではないと判断する。したがって再分配政策に賛成するのである。

そして,世代間学歴移動の社会的効果という観点から見れば, HH が最も再分配に 賛成しくいこと，つまり格差拡大効果が予想できる。

\section{4. 再分配政策への替否に関する経済学的研究}

最後に，再分配政策への賛否に関する経済学的研究の検討を行う。これまでの経 済学的研究の問題点は学歷の指標化に失敗しているということである。これは言い 換えれば，理論に縛られて，データから湧き上がってくるものを見過ごしてしまっ ているという問題である。 
世代間学歴移動の社会的効果

再分配政策への賛否に関する経済学的研究では, 機会が均等であると信じた人ほ ど，あるいは，社会で成功するためには個人の努力が重要だと考えた人ほど，再分 配政策に反対するという仮説を設定している（Alesina and Ferrara 2001，大竹・ 富岡 2003, 篠崎 2005)。しかし，それではどのような人々が機会が均等であると 信じているのかということは考慮されていない。もし仮に，高い社会的地位を父親 から継承した人ほど機会が均等だと考えているとしたら，見せかけのメリトクラシ 一のもとに再分配政策に反対するという判断がなされてしまうことになる。実態レ ベルで格差が生じているにもかかわらず，意識レベルで機会は開放的だと信じられ ることによって再分配政策が行われなくなるとしたら，実態としての格差を継続的 に拡大させていってしまうことになろう。

具体的な研究をいくつか見てみよう。Alesina and Ferrara（2001）は米国の総合 社会調査（General Social Survey：GSS）のデータを用い, 篠崎（2005）は日本版 GSS（JGSS）のデータを用いて，次のような仮説を設定している。「父親より高水 準の教育機会に恵まれた者は，(上方への)階層間移動の存在に肯定的になると考え られるから，再分配政策を否定する」というものである。しかしながら，分析結果 は予想と反対で，父親より高水準の教育を受けた場合に所得再分配に賛成するとな つている(2)。Alesina and Ferarra および篠崎はその結果を, 世代を経るにつれてよ り上位の教育機会が広く提供されるようになったため，学歴は階層移動を測る指標 として有効でなくなってしまった可能性があると解釈している。本論文が論駁しよ うとするのはこの解釈である。

これらの研究による学歴の指標化の間違いは, 図にしてみるとわかりやすい。図 2 で考えると, 経済学の先行研究の仮説では, $\mathrm{CC}-\mathrm{HH}$ (点線)を基準として $\mathrm{HC}$ ら $\mathrm{CH}$ に近くなる（矢印）ほど再分配政策に賛成しにくいと想定されていた。それ に対し，本論文では， $\mathrm{HC}-\mathrm{CH}$ (点線)を基準として CC から $\mathrm{HH}$ に近くなる (矢印) ほど再分配政策に賛成しにくいとするということである。もう少し具体的に述べる と, 先行研究では図 $2(1)$ 網掛けの部分が学歴上昇移動ダミー変数の「 1 」, その他 が「0」となっている。それに対し，図 2 (2)の CC と HH の間に大きな違いが出る と想定し,特に網掛けになっている $\mathrm{CH}$ と $\mathrm{HH}$ の差異に着目しながら新たな解釈を 試みようというのが本論文の主張となる。こうした点は, クロス表を一つ出せば確 認できるものであり，データから発見できる差異を見過ごしてしまっているという 問題点を指摘できよう。

これまでの経済学的研究と本研究の違いは，世代間学歴移動の変数の投入の仕方 
を変えることで新たな解釈を試みるという点である。具体的には，世代間学歴移動 をすべてダミー変数化し，特に $\mathrm{CH}$ と $\mathrm{HH}$ に焦点を当てて，世代間学歷移動の影響 を詳細に検討するということである。

図 2 先行研究の仮説と本研究の仮説

(1) 先行研究の仮説

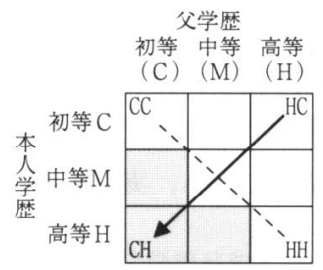

先行研究では, $\mathrm{CH}$ が最も 再分配政策に賛成しにく いとされている。
(2) 本研究の仮説

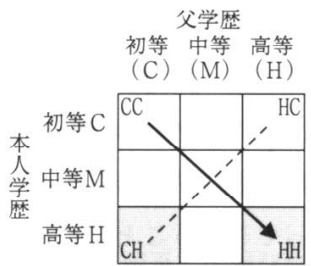

本研究では，CHより HHの ほうが再分配政策に替成 しにくいとする。

再分配政策への賛否に関する経済学的研究に見られるような移動の指標化の間違 いは, 初期の社会移動の研究でも見られた。社会移動が社会的態度に与える影響に ついて, 日本社会学会報告書（日本社会学会調査員編 1958）が社会的態度に与え る社会移動の効果はないという詰った判断を行ってしまったのである。その理由を, 安田（1971，p. 523）は以下のように検討している。それは，「上層非移動者と下層 非移動者とは社会的態度において両極端を示すのに両者を合併してただ非移動者と なし, 上昇移動者と下降移動者とは社会的態度においてあまり異ならないのに, 両 者を別々のグループとして扱ったため」（p. 523）であるというのである。既に挙げ た経済学の先行研究が犯した䛊りについても,この批判がそのままあてはまる。

既述の経済学的研究では, 父親が高等教育で本人が高等教育であるといった高学 歴を継承した人 $(\mathrm{HH})$ と, 父親が義務教育で本人が義務教育であるといった低学歴 を継承した人 (CC) との間には, 再分配の賛否という観点では全く違った態度をと っているにもかかわらず, 両者を合併して学歴上昇移動に該当しない人（ダミ一変 数で「 $0 」)$ として一くくりにされてしまっている。また，父親が義務教育で本人が 高等教育に学歴上昇した人 $(\mathrm{CH})$ も, 父親が高等教育で本人が義務教育である人 （HC）は再分配の賛否に関してあまり異ならないのに両者を別々のグループとして 扱っているのである。その結果, データから沸きあがってくるはずの差異を拾い上 げることができなくなってしまったのである。こうした事態に対し, 学歴移動の違 いを考慮していけば違う解釈が可能になるというのが, 本論文の主張である。 
世代間学歴移動の社会的効果

以上のような先行研究の状況から，本研究では社会意識の研究で着目されること のなかった再分配政策への賛否について, 社会学的な要因を考慮した上で検討して いくことにする。この作業は社会学における社会意識研究に社会的背景との関連を 取り戻すためにも必要不可欠な課題である。その際, 社会学の先行研究の長所であ る, データから湧き上がってくるものを適切に拾い上げるという点は生かされるこ とになる。そこで本論文では, 学歴移動の中身を詳細に検討していくことで, 世代 間学歴移動と再分配政策への賛否との関係についての新たな解釈を試みたい。

\section{4. データと仮説と変数}

\section{1. データ}

本論文で使うのは，「生活と意識についての国際比較調査(日本版 General Social Survey)」(以下，JGSS と記す)の2000-2003年の調査結果である。これら 4 年分を プールして扱うことにする。JGSS は, 東京大学社会科学研究所と大阪商業大学比較 地域研究所が実施した調査である。調査対象は全国満20-89歳の男女個人である。標 本抽出は層化 2 段無作為抽出法で, 全国を18層に分けて調査している。調査時点は 各年とも10-11月である。調查方法としては, 職業や世帯構成などの項目を主に面接 調查で尋ね, その他の生活意識などの項目は留置き調査票に自記の後, 郵送で回収 している。本論文の分析にはこの 2 つの調査票の項目を使うことにする。

標本数について説明する。単純には 4 年で約 12000 の標本数が得られる計算である が, 以下の 2 つの理由から実際に本論で扱う標本数は 4300 ほどとなる。第一に, 本 稿で重要な父学歴や所得といった変数に関する質問項目に回答していない標本がか なりあるということである。第二に，2003年調査では調査票が $\mathrm{A}$ 票と B 票の 2 種類

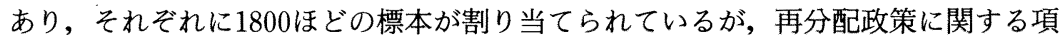
目が $\mathrm{A}$ 票にしか含まれていないためである。

\section{2. 仮説と変数}

ここでは, 仮説と変数を説明していくことにする。まず, 従属変数を説明し, 次 にメインの独立変数を説明し, 最後に先行研究が蓄積してきたコントロール変数を 検討する。

\section{再分配政策への支持}

質問文は，「『政府は，裕福な家庭と貧しい家庭の収入の差を縮めるために，対策 
をとるべきだ』という意見に，あなたは賛成ですか，反対ですか」である。これに 対する回答は，1：賛成，2：どちらかといえば賛成，3：どちらともいえない, 4 : どちらかといえば反対， 5 ：反対の中から選択することになっている。本論文 では, $1:$ 賛成 (=1 : 賛成 $+2 ：$ どちらかといえば賛成), 0 ：その他というダミ 一変数を作成した。

\section{世代間学歴移動}

次に，メインの独立変数である世代間学歴移動の変数を検討する。

本人学歷と父学歴の分類については, 先行研究にならつて, 義務教育, 中等教育, 高等教育の 3 つ分類した。義務教育とは, 旧制尋常小学校, 旧制高等小学校, 新制 中学校である。中等教育とは, 旧制中学校, 高等女学校, 旧制実業学校, 新制高校 であり, 高等教育とは, 旧制師範学校, 旧制高校・旧制専門学校・高等師範学校, 旧制大学・旧制大学院, 新制大学, 新制大学院である。

先行研究では, 学歷が高いほど, 高い所得水準に到達できる可能性が高いので, 再分配政策に反対すると考えられてきた。しかし，すでに検討してきた準拠集団の 議論から考えれば，むしろ高等教育学歴を継承した人の方が再分配政策に反対しや すいと考えられる。そこで本論文では, 本人学歴と父学歷の移動の影響を見たいの で, 本人学歴と父学歴の関係を交互作用としてダミー变数を投入した ${ }^{(3)}$ 。例えば $\mathrm{HH}$ ダミーとは, 父親も本人も高等教育学歷の人を「 1$\rfloor$, その他の人を「0」とするダ ミー変数である。

本論文のメインの仮説は, 先行研究の検討を踏まえると以下にまとめられる。

\section{仮説 $\mathrm{HH}$ は CHよりも再分配政策に養成しにくい。}

世代間学歷移動の社会的効果という観点からすれば， $\mathrm{HH}$ が $\mathrm{CH}$ よりも再分配政 策に賛成しにくいという点が格差拡大効果である。 $\mathrm{HH}$ という社会経済的に有利な 地位を継承した人が再分配に反対するということは，格差拡大を継続的に増幅させ ていくメカニズムを内包しているということだからである。

以上に述べた仮説を解釈しやすくするため, 基準変数を $\mathrm{CH}$ としてダミー変数を 投入し, $\mathrm{HH}$ との違いが明確になるようにした。

最後に, 先行研究が蓄積してきた変数を統制変数として紹介していく。

\section{女性ダミー}


世代間学歴移動の社会的効果

これは性別に関する変数である。女性は, 男性に比べて社会的な機会に恵まれて いないため，再分配政策に賛成しやすいと考えられる ${ }^{(4)}$ 。

\section{年齡}

年齢が高いほどより高い所得水準に到達できる可能性が低下するため, 再分配に 賛成すると考えられる。年齢はそのまま連続変数として投入した。

たしかに, 学歴の意味は, 年代とともに変化するということも考えられる。これ に対して本論文では，年齢をコントロールすることで対処することにする。年齢を コントロールしても世代間学歴移動の効果が見られれば, 学歴移動の影響があると 判断できよう(5)。

\section{世帯所得}

世帯所得が高いほど再分配政策に反対すると考えられる。世帯所得は自然対数値 をとって投入した。

\section{職業威信スコア}

職業威信スコアが高い人ほど再分配政策に反対すると考えられる。そこで，職業 威信スコアを投入した。

以上, 変数と仮説を検討してきた。記述統計量は表 1 にまとめた。それでは分析 に移ることにしよう。

表 1 記述統計量

\begin{tabular}{|c|c|c|c|c|c|c|c|}
\hline & & & 度数 & 最小値 & 最大値 & 平均値 & 標準偏差 \\
\hline 従属変数 & \multicolumn{2}{|c|}{ 再分配政策への賛成 } & 4312 & 0 & 1 & 0.526 & 0.499 \\
\hline \multirow{4}{*}{ 統計変数 } & \multirow{4}{*}{\multicolumn{2}{|c|}{ 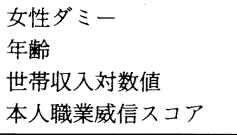 }} & 4312 & 0 & 1 & 0.415 & 0.493 \\
\hline & & & 4312 & 20 & 88 & 47.430 & 13.062 \\
\hline & & & 4312 & 3.56 & 7.74 & 6.409 & 0.665 \\
\hline & & & 4312 & 36.70 & 90.10 & 50.398 & 8.563 \\
\hline \multirow{9}{*}{$\begin{array}{l}\text { 世代間 } \\
\text { 学歴移動 } \\
\text { 変数 }\end{array}$} & \multirow{3}{*}{$\begin{array}{c}\text { 本人 } \\
\text { 初等教育 }\end{array}$} & CC ダミー & 4312 & 0 & 1 & 0.102 & 0.303 \\
\hline & & $\mathrm{MC}$ ダミー & 4312 & 0 & 1 & 0.010 & 0.099 \\
\hline & & HC ダミー & 4312 & 0 & 1 & 0.001 & 0.030 \\
\hline & \multirow{3}{*}{$\begin{array}{c}\text { 本人 } \\
\text { 中等教育 }\end{array}$} & CM ダミー & 4312 & 0 & 1 & 0.242 & 0.429 \\
\hline & & MM ダミー & 4312 & 0 & 1 & 0.127 & 0.333 \\
\hline & & HM ダミー & 4312 & 0 & 1 & 0.032 & 0.175 \\
\hline & \multirow{3}{*}{$\begin{array}{c}\text { 本人 } \\
\text { 高等教育 }\end{array}$} & CH ダミー & 4312 & 0 & 1 & 0.097 & 0.296 \\
\hline & & MH ダミー & 4312 & 0 & 1 & 0.116 & 0.320 \\
\hline & & HH ダミー & 4312 & 0 & 1 & 0.105 & 0.306 \\
\hline
\end{tabular}




\section{5. 分析}

\section{1. 本人学歴と父学歴の関係}

まず，本人学歴と父学歴の関係を確認することにする。図 3 を見ると分かるよう に, 父学歴は年代を通じて一貫して本人学歴に影響を与えている。 $70 ・ 80$ 代の場合, 父が義務教育卒，高等教育卒の人のうち高等教育に進学できたのはそれぞれ $12.3 \%$ と64.3\%である。こうした差は 20 代においても見られる。父が義務教育卒，高等教

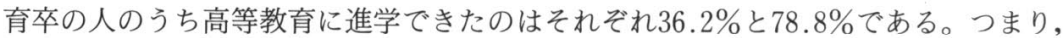
年代を越えて高等教育進学の格差は父学歴によって規定されているのである。

父学歷が高等教育であるということは，本人が高等教育学歴を得るに際して，有 利な地位を持っているということである。

\section{図 3 父学歴別高等教育進学率}

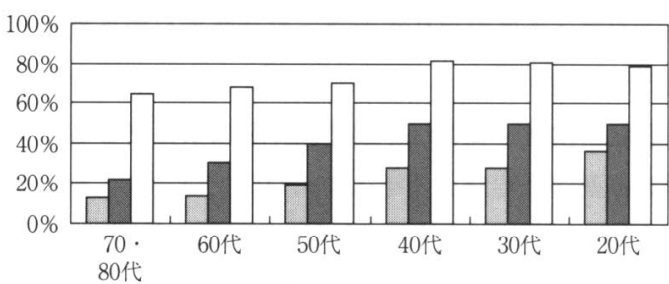

口父初等教育 曰父中等教育 ロ父高等教育

\section{2. 世代間学歴移動と再分配政策への賛否}

次に，本人学歴と父学歴と再分配政策への賛否の関係について検討する。図 4 を 見ると，本人の学歴が高等教育であるときに，父学歷が特に影響を与えていること が分かる。同じ高等教育学歴の人のなかでも父義務教育 $(49.6 \%) \rightarrow$ 父中等教育 $(45$. $9 \%) \rightarrow$ 父高等教育 $(39.8 \%)$ の順で，再分配政策に賛成しにくいという関係になっ ている。先行研究の前提からすれば，父義務教育から本人が高等教育に上がった人 (CH) が最も再分配政策に賛成しにくいとされてきた。しかし，デー夕を見る限 り，本人が高等教育の人についてみれば，学歴上昇移動した人よりも高等教育学歴 を継承した人のほうが再分配に賛成しにくいという傾向が見られるのである。

先行研究のところで確認した図 2 との関連を考えると，本人が同じ高等教育学歴 であっても，父学歷が義務教育の場合（49.6\%）よりも，父が高等教育である場合 
(39.8\%) のほうが再分配に賛成しにくいことが確認できる ${ }^{(6)}$ 。父親よりも学歴が上 がった人のほうが再分配に賛成しやすく，有利な地位を継承した層が最も再分配に 賛成しにくい様子が見て取れるのである。性別・年齢・収入・職業威信スコアとい った他の要因も統制した上でこの関係が維持されていれば，世代間学歷移動が再分 配への賛否に与える影響を検証できるだろう。

図 4 父学歴・本人学歴別再分配賛成率

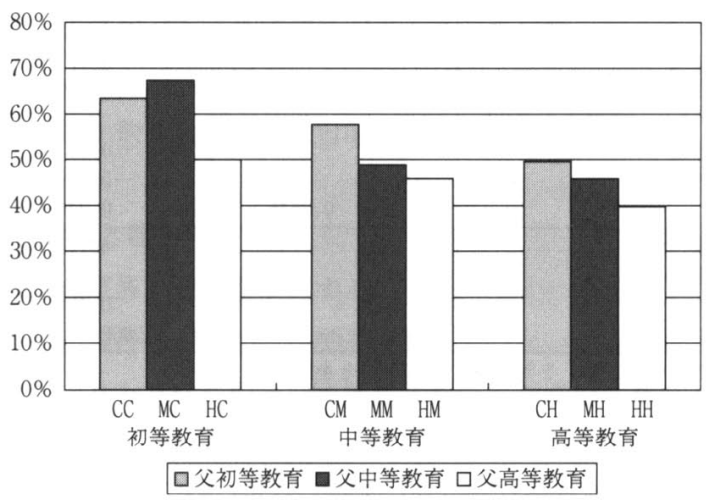

\section{3. 再分配政策への賛否に関するロジスティック回帰分析}

そこで，最後に他の要因を統制した上で学歷移動の効果を見ることにする。表 3 は，再分配政策への賛否を従属变数としてロジスティック回帰分析を行ったもので ある。

まず，これまでの先行研究で挙げられてきた変数のみを投入したものがモデル 1 である ${ }^{(7)}$ 。女性ダミーについては, 負で有意であり，女性ほど再分配政策に賛成しに くいという先行研究どおりの結果が得られている。次に，年齢である。これについ ては，年齢が上がるほど再分配政策に賛同するようになることが確認できる。最後 に，世帯収入と職業威信スコアである。これを見ると係数が負であり，世帯収入が 高いほど再分配政策に反対するという予想どおりの結果が得られたことがわかる。 それでは，学歷移動の影響を検討することにしよう。モデル 1 に学歴移動の変数 を投入したのがモデル 2 である。尤度比検定を行うと,5828.46-5806.20=22.26(自 由度 8 ）で，1％水準でモデル 2 が有意である。

世代間学歴移動の影響を詳細に見ていくことにしょう。仮説は, $\mathrm{CH}$ よりも $\mathrm{HH}$ 
表 2 再分配政策への劷成についてのロジスティック回帰分析

\begin{tabular}{|c|c|c|c|c|c|c|c|}
\hline & \multicolumn{3}{|c|}{ モデル 1} & \multicolumn{3}{|c|}{ モデル 2} \\
\hline & & $\mathrm{B}$ & $\begin{array}{l}\text { 標準 } \\
\text { 詔差 } \\
\end{array}$ & $\begin{array}{l}\text { Exp } \\
\text { (B) }\end{array}$ & B & $\begin{array}{l}\text { 標準 } \\
\text { 誤差 } \\
\end{array}$ & $\begin{array}{l}\text { Exp } \\
(\mathrm{B})\end{array}$ \\
\hline & 女性ダミー & -0.23 & $0.06^{* *}$ & 0.79 & -0.22 & $0.06^{* *}$ & 0.80 \\
\hline & 年齢 & 0.01 & $0.00^{* *}$ & 1.01 & 0.01 & $0.00^{* *}$ & 1.01 \\
\hline & 世帯収入 & -0.28 & $0.05^{* *}$ & 0.76 & -0.25 & $0.05^{* *}$ & 0.78 \\
\hline & 職業威信スコア & -0.02 & $0.00^{* *}$ & 0.98 & -0.02 & $0.00^{* *}$ & 0.98 \\
\hline & $\mathrm{CC}$ ダミー & & & & 0.13 & 0.12 & 1.14 \\
\hline 本人 & MC ダミー & & & & 0.41 & 0.33 & 1.50 \\
\hline 初寺 & $\mathrm{HC}$ ダミー & & & & -0.22 & 1.01 & 0.81 \\
\hline & CM ダミー & & & & 0.13 & 0.09 & 1.13 \\
\hline 本人 & MM ダミー & & & & -0.17 & 0.11 & 0.84 \\
\hline & HM ダミー & & & & -0.28 & 0.18 & 0.75 \\
\hline & $\mathrm{CH}$ ダミー（基準カテゴリ） & & & & & & \\
\hline 本人 & $\mathrm{MH}$ ダミー & & & & -0.12 & 0.11 & 0.89 \\
\hline & HH ダミー & & & & -0.32 & $0.12^{* *}$ & 0.72 \\
\hline & 定数 & 2.63 & $0.36^{* *}$ & 13.80 & 0.93 & $0.68^{* *}$ & 11.33 \\
\hline & 標本数 & 4312 & & & 4312 & & \\
\hline & 自由度 & 4 & & & 12 & & \\
\hline & $\mathrm{p}$ 值 & 0.00 & & & 0.00 & & \\
\hline & -2 対数尤度 & 5828.46 & & & 5806.20 & & \\
\hline
\end{tabular}

※ **, *はそれぞれ 1\%, 5 \%水準で有意なことを示す。

のほうが再分配政策に賛成しにくい，というものであった。表 2 の HH ダミーの係 数を見ると, $\mathrm{CH}$ を基準カテゴリーとして負で有意になっている。つまり， $\mathrm{CH}$ より も $\mathrm{HH}$ のほうが再分配政策に賛成しにくいということである。これにより仮説が検 証されたと言えよう。世代間学歴移動の社会的効果という観点から見れば，格差拡 大効果が確認できたのである。

\section{6. 考察と課題}

\section{1. 世代間学歴移動の社会的効果}

以上，再分配政策への賛否に対して世代間学歴移動が与える影響を検討してきた。 そこからわかったのは, 高等教育学歴を継承した人 $(\mathrm{HH})$ は, 父親が義務教育学歴 で本人が高等教育学歴に上昇してきた人 $(\mathrm{CH})$ よりも，再分配政策に賛成しにくい ということであった。これは，世代間学歴移動の社会的効果という観点から考えれ ば，格差拡大効果である。

こうした世代間学歴移動の機能から導かれる政策提言は，父学歴という点で不利 な地位に立っている人に高等教育学歴の機会を開いていくということである。なぜ なら，高学歴を継承した人 $(\mathrm{HH})$ よりも父親が義務教育学歴で本人が高等教育学歴 に上昇してきた人 $(\mathrm{CH})$ のほうが再分配政策に賛成しやすくなるからである。この 
ように述べると本論文の主張は, 「機会を均等にせよ」という従来の教育社会学の研 究と変わらないように見えるかもしれない。しかしながら，本論文の主張はただ機 会を均等せよというだけではない。そうではなく, 機会の均等を拡大することが再 分配政策への賛成を通してさらなる機会の均等を導くというメカニズムである。逆 に, 格差拡大機能に着目するならば, 機会の不均等を拡大させることが再分配への 反対を通してさらなる機会の不均等を導くという危険性があるのである。つまり， 今後高等教育の拡大に伴って $\mathrm{CH}$ が減り $\mathrm{HH}$ が増える中で, 何らかの手を打たなけ れば再配分政策への反対が高まる可能性があることを示唆しているのである。

そして, 以上のような示唆を得たことによって，階層㷌属意識研究が失ってきた 社会的背景との関連を取り戻すという目的も達成できたと言えよう。

\section{2. 本論文の限界と課題}

最後に，本論文の限界と課題を検討する。

本論文の限界は, 高等教育内部の移動を考慮していないということである。父親 の受けた高等教育よりもレベルの高い高等教育を受けた場合，その人は学校歴とい う点で見れば上昇移動したと考えることもできるかもしれない。本論文では，その 点を考慮できていない。もちろん，学校歴という点で上昇移動したとしても，父親 が高等教育学歴であることが社会経済的に見て圧倒的に有利な地位にあることには 変わりはないことは, 図 3 で確認してある。しかし，モデルを精緻化していくとい う点では必要な作業であると考えられる。今後質問紙を工夫することでこの課題に 応えていきたい。

\section{〈注〉}

（1）吉川（1998）は，「価値志向」や「志向性」との区別に着目しながら，「社会的 態度」という用語を用いるメリットを議論している。そこでここではその用語法 にならって，「社会的態度」を「具体的な行為を行うことを前提として諸個人がと る, 心的準備状態」のうち,「社会学的な観点で検討される」(26頁)ものと定義 しておく。

（2）独自の社会調査を行って分析を試みた大竹・富岡（2003）は, 父学歴と本人学 歴との変化は有意にならなかったとしている。

（3）社会移動の効果を交互作用項として投入することによって測定することについ ては，和田（1986）を参照した。 
（4）ただし，篠崎（2005）では，日本の場合仮説に反して，女性は再分配に賛成と いう立場をとりにくく，むしろ中立的な立場をとりやすいことが明らかにされて いる。

（5）この点, 高学歴化が進むにしたがって高等教育学歴を取得しても高い収入を得 ることができない人が増え, そのため再分配に賛成しやすくなるということも考 えられる。しかし，だとするならば HH の人も賛成しやすくなるはずであり，本 論文にとっては下方バイアスがかかっていることになる。本論文が示すのは，そ うした下方バイアスがあったとしても $\mathrm{CH}$ と $\mathrm{HH}$ との間に差があるという点で ある。

（6）準拠集団の仮説を考慮すれば， $\mathrm{CC}$ は $\mathrm{MC} ・ \mathrm{HC}$ よりも， $\mathrm{MM}$ は $\mathrm{CM} ・ \mathrm{HM}$ より も賛成しにくいという関係も考えられる。しかしながら, すでに述べたように再 分配政策への政治的影響力と高等教育拡大の効果を考えるという観点から，以下 の分析では $\mathrm{CH}$ と $\mathrm{HH}$ に焦点を当てて検討していくことにする。

（7）その他, 先行研究で投入されていた変数を投入したが, $\mathrm{HH}$ ダミーが有意である ことに変化は見られなかった。変数名とその説明は以下の表にまとめた。特に注 目すべきは「職業威信スコア上昇ダミー」を統制しても，世代間学歴移動の効果 が見られたということである。つまり，職業の世代間移動を考慮しても世代間学 歴移動の効果が確認できたのである。もちろん職業カテゴリーごとの違いを詳細 に見ていくことも必要な作業であるが，父親の職業と本人の職業との組み合わせ となると大変煩雑になってしまう。ここでは, 職業威信スコアの変化を考慮して も世代間学歴移動の効果が見られたことを確認し，職業カテゴリーごとの詳細な 分析は今後の課題としたい。

表 光の他の追加変数

\begin{tabular}{|c|c|}
\hline 変数名 & 変数の説明 \\
\hline 末婚ダミー & 未婚の人を「 1$\rfloor$, その他の人を「0」とするダミー変数 \\
\hline 子どもダミー & 子どもが居る人を「 1$\rfloor$, その他を「 $0 」$ とするダミ一変数 \\
\hline $\begin{array}{l}\text { 職業威信スコア } \\
\text { 上昇ダミー }\end{array}$ & $\begin{array}{l}\text { 父親より威信スコアが上昇した人を「 } 11 」 \text {, その他を「0」とするダミー変 } \\
\text { 数 }\end{array}$ \\
\hline 将来の失業可能性 & $\begin{array}{l}\text { 今後 } 1 \text { 年間に回答者が失業する可能性を感じている場合に「1」をとるダ } \\
\text { ミー。 }\end{array}$ \\
\hline 経済状態変化 & 過去 $2-3$ 年の間に経済状態が悪化した場合に「1」をとるダミー。 \\
\hline 生活水準を向上させる機会 & $\begin{array}{l}\text { 今の日本社会には, 回答者や回答者の家族の生活水準を向上させる機会が } \\
\text { ないと考えている場合に「1」をとるダミー。 }\end{array}$ \\
\hline 健康状態 & $\begin{array}{l}\text { 健康状態が悪い場合に「1」, 良い場合に「5」をとる } 5 \text { 点尺度の順序変 } \\
\text { 数。 }\end{array}$ \\
\hline
\end{tabular}


世代間学歴移動の社会的効果

\section{〈参考文献〉}

Alesina, Alberto and Ferrara, Eliana La 2001,, ' Preference For Redistribution in the Land of Opportunities', NBER Working Paper 8267.

Blau, Peter M. 1956. 'Social Mobility and Interpersonal Relations.' American Sociological Review 21 3,: pp. 290-295.

星敦士, 2001, 「階層㷌属意識の判断メカニズムー地位認知に対するパーソナルネッ

トワークの影響一」『総合都市研究』第76号 pp. 57-67.

今田幸子, 1979, 「学歴構造の趨勢分析」富永健一編『日本の階層構造』東京大学出 版会.

片岡栄美, 1988,「三世代学歷移動の構造」1985年社会階層と社会移動の全国調査委

員会編『1985年社会階層と社会移動の全国調査報告書』.

荻谷剛彦, 2001, 『階層化日本と教育危機一不平等再生産から意欲格差社会へ一」。 吉川徹, 1998, 『階層・教育と社会意識の形成 : 社会意識論の磁界』ミネルヴァ書 房.

吉川徹, 2005, 「学歴の世代間移動を考える」日本教育社会学会第57回大会報告資 料.

菊池城司, 1990,「現代日本における教育と社会移動」菊池城司編『現代日本の階層 構造(3)教育と社会移動』東京大学出版会.

高坂健次, 2000, 『社会学におけるフォーマル・セオリー：階層イメージに関する $\mathrm{FK}$ モデル』ハーベスト社.

Merton, R. K., 1949, Social Theory and Social Structure, New York, The Free Press=ロバート・K・マートン：森東吾ほか訳 1961, 『社会理論と社会構造』 みすず書房.

直井道子, 1979, 「階層意識と階級意識」富永健一編『日本の階層構造』東京大学出 版会。

日本社会学会調査委員会編, 1958, 『日本社会の階層構造』有斐閣. 大竹文雄・富岡淳, 2003, 「誰が所得再分配政策を支持するのか？」内閣府経済社会

総合研究所 Discussion Paper Series No. 40. 斎藤友里子, 1998,「階層システムにおける不平等の認識についてー数理モデルによ

る分析の試み一」『奈良女子大学文学部研究年報』第42集 pp. 69-86. 佐藤俊樹，2000，『不平等社会日本』中公新書. 盛山和夫, 1990 ,「中意識の意味」『理論と方法』 第 8 号 : pp. 51-71. 
篠崎武久, 2005,「再分配政策への支持を決定する要因一先行研究の結果と JGSS デ 一夕を用いた分析結果の比較一」東京大学社会科学研究所『JGSS 研究論文集 [4]』.

大竹文雄・富岡淳，2003，「誰が所得再分配政策を支持するのか？」内閣府経済社会 総合研究所 Discussion Paper Series No. 40.

和田修一, 1986,「社会の階層構造が与える心理的影響」研究をめぐる理論と方法」 理論と方法 Vol. 1 No. 1 pp. 41-56. 安田三郎, 1971, 『社会移動の研究』東京大学出版会.

謝辞〔二次分析〕に当たり, 東京大学社会科学研究所附属日本社会研究情報セ ンターSSJ データアーカイブから日本版 General Social Surveys（JGSS：寄 託者は, 大阪商業大学比較地域研究所及び東京大学社会科学研究所）の個票デ 一夕の提供を受けました。JGSS は, 大阪商業大学比較地域研究所が, 文部科学 省から学術フロンティア推進拠点としての指定を受けて（1999-2003年度), 東 京大学社会科学研究所と共同で害施している研究プロジェクトです。(研究代 表：谷岡一郎・仁田道夫, 代表幹事：佐藤博樹・岩井紀子, 事務局長：大澤美 苗)。データの入手先は, 東京大学社会科学研究所附属日本社会研究情報セン夕 ーSSJデータアーカイブです。データ提供についてここに記して感謝申し上げ ます。 
ABSTRACT

\title{
Social Effect of Intergenerational Academic Background Mobility: Focusing on the Pros and Cons for Redistribution
}

\author{
AND0, Satoru \\ (Graduate School, University of Tokyo) \\ 7-3-1 Hongo, Bunkyo-ku, Tokyo, 113-0033 Japan \\ Email: andosatoru@ hotmail.com
}

Studies in the sociology of education have not paid sufficient attention to the social effects of intergenerational academic background mobility. Intergenerational academic background mobility means the change between an individual' $\mathrm{s}$ academic background and that of his/her father. This paper examines support for redistribution to clarify the effect. Using the integrated data of JGSS-2000, 2001, 2002 and 2003, the author finds that college graduates whose fathers are also college graduates tend to not support redistribution compared to college graduates whose fathers are graduates from compulsory education alone. This means that intergenerational academic background mobility has a gap-widening effect. People who receive an advantage by the fact that their own fathers are college graduates tend to not support redistribution, implying that the gap will continuously expand.

The policy implication of this paper is that as the percent of students pursuing higher education increases, people who tend to not support redistribution will also increase. It is possible, thus, that it will become more difficult for policy makers to implement redistribution policies. 